\title{
Success in Fulfilling Greek Teachers' Needs in Environmental Education through an In-service Training Course in the Maraslios Teacher Training School
}

\author{
Achilleas Mandrikas \\ School Advisor in Primary Education, $\mathrm{PhD}$ in Environmental Science Education \\ E-mail: amandrik@otenet.gr
}

Evangelia Mavrikaki

Assistant Professor, Faculty of Primary Education,

National and Kapodtistrian University of Athens

E-mail: emavrikaki@primedu.uoa.gr

Constantine Skordoulis

Professor, Faculty of Primary Education,

National and Kapodtistrian University of Athens

E-mail: kostas4skordoulis@gmail.com

Received: October 10, 2013 Accepted: October 28, 2013 Published: November 1, 2013

doi:10.5296/jse.v3i4.4405

URL: http://dx.doi.org/10.5296/jse.v3i4.4405

\begin{abstract}
This paper illustrates a 4-year case study (2008 - 2012) regarding a course in environmental education that was designed for the training of 58 practicing Greek in-service elementary teachers. The aim of the study was to reveal if a six-month Environmental Education training course succeeded in fulfilling Greek in-service teachers' needs in Environmental Education. This was achieved through an assessment of the course by the participants. Their answers to four open-ended questions were analyzed following the principles of content analysis. Results revealed that in-service teachers considered their participation in the course
\end{abstract}




\section{Macrothink}

as useful for their professional development and mostly valued their active engagement in learning activities, the experience they gained being a learner, the fact that the course was designed so that they could - with minor adjustments -transfer it to their classroom. They also valued the fact that the course was designed trying to connect theory with practice and it was based on collaborative group work and experiential activities according to appropriate methods and approaches. Challenges in developing the course included the teachers' different previous experience in environmental education and teachers' need for practical work.

Keywords: In-service teachers, Elementary teachers, Teacher training, Environmental education, Content analysis 


\section{Introduction}

In the framework of the UN Decade of Education for Sustainable Development (2005 2014), appropriate teacher training was proposed as one of the areas for action (Monroe and Fien, 2005; Sauvé and Berryman, 2005; UNESCO, 2005). In order for EE to be developed successfully, research shows that teachers themselves must be properly trained, both during their undergraduate studies (Heimlich et al., 2004; Powers, 2004) and during their work in schools (Gayford, 2002; Klein, 2005; Stevenson, 2007). In these courses, particular emphasis should be given to the social dimension of EE, which is linked on the one hand to critical education (Carr and Kemmis, 1986; Gibson, 1986; Giroux and McLaren, 1994) and on the other to social justice (Dobson, 1998; Freire, 1972; Locke, 2009). The success of these training courses depends on a successful combination of scientific knowledge of environmental issues, an appropriate educational methodological approach to them, their philosophical and scientific background and an awareness of their social consequences (see Carolan, 2006; Carter 2007; Littledyke, 2008; Meichtry et al., 2001).

In Greece, most teachers working in EE today at all levels of the education system did not have the opportunity to study the subject at university (Fikaris, 1998). EE was included late on in undergraduate teaching studies, at the beginning of the 1990s. Since then, Environmental Science and Environmental Education courses have been introduced in all Greek universities' Pedagogical Faculties (Flogaitis, 1998) and in many other university faculties whose graduates could choose a career in education (Skordoulis and Sotirakou, 2005).

Today, however, it is generally accepted that 'the professional development of teachers is a lifelong process which begins with the initial preparation that teachers receive (whether at an institute of teacher education or actually on the job) and continues until retirement' (Villegas-Reimers, 2003, p. 8), therefore EE courses have been embedded in all forms of in-service teacher training, whether formal or informal.

\section{The Case of the 'Maraslios Teacher Training School'}

The Maraslios Teacher Training School was for many years the only in-service training establishment for elementary school teachers. It was set up in 1922 in Athens with the goal of renewing teachers' pedagogical knowledge over the course of their career. A teacher could attend Maraslios just once in his/her career, having passed exams in three subjects (Pedagogical Psychology, Teaching Methodology, and Modern Greek Literature). Training lasted 2 years and teachers were required to attend daily classes.

From 1995 Maraslios came under the authority of the Pedagogical Education Faculty of the University of Athens, so the level of studies was upgraded and courses were enhanced. All courses emphasized the need for teachers to gain theoretical tools as well as teaching abilities and class sizes were set at between 10 and 24 participants.

Meanwhile, similar institutes were being established in 6 Greek cities (Thessaloniki, Patras, Ioannina, Alexandroupoli, Rethymnon and Rhodes) with existing Teacher Training Faculties. Any teacher who had worked for more than 5 and fewer than 25 years was eligible to attend 
the teacher training courses. For the vast majority of teachers, Maraslios and the other Institutes were the only source of training, updating their knowledge, research and reflection they would experience in a 35-year career in Elementary Education. Unfortunately, Maraslios and all these institutes were discontinued in 2012, without having yet been replaced by any other form of training.

\section{Principles of Design and Methodology of the Environmental Education course}

Several efforts at in-service teacher training in EE have been made all over the world. In spite of the interest in the direct learning results of many of these training courses (see Lee et al., 2004; Papadimitriou, 1995; Sandholtz, 2002; Summers, Corney and Childs, 2003) In recent years there has been much discussion and research interest in the methodology used in these training programmes (see Christie et al., 2012; Kelley, 2010; Kemmis and Mutton, 2012).

The design of the course was based on teachers' training needs in EE as this has been recorded in the Greek (Antoniou, 2010; Daskolia, 2000; Daskolia \& Flogaitis, 2003; Dimopoulou \& Babila, 2010; Kaztaridou, 2007; Michail et al., 2008; Papaioannou et al., 2010) and international literature (Fleming, 2010; Omoogun \& Omoogun, 2013).

According to Klein (2001) there are 18 Guidelines for Effective Elementary Science Teacher In-Service Education. We implemented these guidelines in the field of EE, in an attempt to cover the widest possible spectrum of teachers' needs and requirements.

\section{The Content of the Environmental Education Course}

The course was structured (Table 1) over 14 2-hour sessions (with minor variations each year):

Table 1. The Contents of the Environmental Education Course

\begin{tabular}{|l|l|}
\hline Lesson & Subject \\
\hline 1 & Introduction, Personal introductions, Goal-setting for the course \\
\hline 2 & $\begin{array}{l}\text { History of EE: Pioneering educational movements, the environmental movement, } \\
\text { international conferences, important texts }\end{array}$ \\
\hline 3 & $\begin{array}{l}\text { EE / Sustainability education: Aim and goals - basic features. Analysis of three } \\
\text { views of EE, based on the positivist, interpretative and critical models led to a } \\
\text { need to distinguish between 'activity' and 'action'. IET were asked to do this by } \\
\text { selecting actions from within an EE school programme. Groups then had to fill in } \\
\text { the 'poverty spiral' showing causal relationships between concepts (see } \\
\text { Mandrikas, 2012). This was a useful introduction to the complex concept of } \\
\text { sustainability, approached through the study of another spiral from a UNICEF } \\
\text { publication (summer 1995), reading an excerpt from Flogaitis' book (2006) and } \\
\text { the presentation of various diagrams on the pillars of sustainability, taken from the } \\
\text { same book. The session ended with the groups discussing the most sustainable }\end{array}$ \\
\hline
\end{tabular}




\begin{tabular}{|c|c|}
\hline & choice among 10 solutions to a problem - case study. \\
\hline 4 & $\begin{array}{l}\text { Environmental Ethics and Education: anthropocentrism, biocentrism, deep } \\
\text { ecology, ecophilosophy, social ecology, ecofeminism, ecosocialism. IET worked } \\
\text { on the difference between anthropocentrism and biocentrism, attempting to } \\
\text { identify elements of each approach in } 10 \text { different answers to } 2 \text { problems } \\
\text { (Mandrikas, 2012). They then studied texts from Skordoulis' (2005) book. Lastly, } \\
\text { they were asked to provide anthropocentric and biocentric answers to } 8 \text { different } \\
\text { questions. }\end{array}$ \\
\hline 5 & EE methodology: Project method, problem solving, specific strategies \\
\hline 6 & $\begin{array}{l}\text { Systemic approach. Graphics were handed out for discussion, the features of } \\
\text { systemic thinking were described (Flogaitis, 2006) and later there was a more } \\
\text { detailed examination of how to apply the systemic approach to EE. As a practical } \\
\text { exercise, IET were given an activity from 'Kallisto' educational materials } \\
\text { (Giannakouras, Zaravela and Mandrikas, 2008), in which they were required to } \\
\text { carry out a thematic and then systemic analysis on the topic of 'Energy Saving in } \\
\text { Schools'. }\end{array}$ \\
\hline 7 & $\begin{array}{l}\text { Critical approach. Along with the theory of critical thought (Gibson, 1986; } \\
\text { Matsagouras, 1998) IET discussed the importance of critical thought that comes } \\
\text { to the fore through EE's social dimension (Carr and Kemmis, 1986; Fien, 1993; } \\
\text { Schiza, 2008). The main tool used in this session was a presentation on 'The } \\
\text { Forest', which recommended a step-by-step approach, starting from the } \\
\text { dimension that is closest to the student and moving progressively to the furthest. } \\
\text { IET had the opportunity to reflect on social processes in which different values, } \\
\text { world views, interests and practices interact, formulating a real-life ideological } \\
\text { critique of a system of values and decisions. This smoothly introduced the } \\
\text { strategy of structured discussion, in a scenario borrowed once again from the } \\
\text { 'Kallisto' educational material (Giannakouras, Zaravela and Mandrikas 2008). } \\
\text { The participants were divided into two groups with opposing views. They both } \\
\text { had to present arguments and convince each other on the advantages and } \\
\text { disadvantages of building a coal-fired power plant near a coastal village. }\end{array}$ \\
\hline $8-9$ & Planning an EE school programme based on the project method \\
\hline $10-11$ & Planning an EE school programme based on the problem solving method \\
\hline 12 & $\begin{array}{l}\text { Focus on specific strategies (role playing, concept maps, brainstorming, review of } \\
\text { ideas) - field studies. }\end{array}$ \\
\hline 13 & EE Educational material - EE online \\
\hline 14 & $\begin{array}{l}\text { Presentation of EE school curricula }-E E \text { in Greece. Institutional bodies (Centres } \\
\text { for Environmental Education, EE coordinators, NGOs, Greek Association of } \\
\text { Environmental Educators), basic features of an EE school programme, steps to } \\
\text { implementing EE in school curricula, strategies for bringing EE into the } \\
\text { educational system }\end{array}$ \\
\hline
\end{tabular}




\section{Research Question}

This work aims to reveal in which extent the designed six-month Environmental Education training course succeeded in fulfilling Greek in-service teachers' relevant needs. This is achieved through an assessment of the course and the participating teachers' appraisal of the positive and negative points of the course and of the useful information they received.

\section{Sample}

Our research sample consists of IET trained in the Maraslios Teacher Training School in the Faculty of Elementary Education at the University of Athens that attended the course 'Environmental Education' over four academic years (2008-2012). The research sample consisted of 58 IET that were willing to participate. Their distribution across academic years was as follows: 12 teachers from 2008-09, 21 teachers from 2009-10, 8 teachers from 2010-11 and 17 teachers from 2011-12. The average age of men was 41.23( \pm 3.94$)$ and women $38.42( \pm 3.38)$ and their average number of working years were $19.07( \pm 4.03)$ and $17.44( \pm 3.28)$ respectively. Only $22 \%$ (13) of the total sample group was male and $78 \%(45)$ was female. It should be noted that the majority of IET in Greece are female.

\section{Method}

A questionnaire consisting of four open-ended questions was designed as the main research tool. The questions were deliberately open-ended so as not to influence the IET in their responses. It is difficult to categorise this type of responses, but they give more detailed, more in-depth information (Babbie, 2011). Fifty-eight (58) IET filled out the questionnaire anonymously, having taken the course at some point between 2008 and 2012. They responded to the questionnaire at the end of each winter semester - at the end of the lecture sequence but before the written exam, which required them to describe the design of an EE school programme on a given topic.

Questionnaire responses have been analyzed on the basis of Content Analysis, following the principles of Quantitative and Qualitative Content Analysis (Berelson, 1984; Grawitz, 2001; Mucchielli, 2006; Weber, 1990). As a unit of analysis we defined the 'meaning unit' (Graneheim and Lundman, 2004) or 'theme' as Lasswell, Merner and de Sola Pool used to name it (Zagkos, Kyridis, Golia, and Vamvakidou,2007) (see also Mavrikaki, Antonatou and Kyridis, 2012).

The authors worked as coders and followed the steps proposed by Berg and Veer (1988) and Weber (1990) and described in Mavrikaki, Antonatou and Kyridis (2012). The definition of the categories was based on the 'grounded' process (Neuendorf, 2002), in other words the teachers' responses were read several times until categorisation was possible. Once categorisation was finalised and the content validity was checked, the three coders (the authors) proceeded to coding a sample of 5 teachers' answers comprising of at least 30 meaning units that are considered an adequate number for the pilot test of intercoder reliability (Lacy and Riffe, 1996). The intercoder reliability was estimated at 88,9\%, which enabled us to proceed. After resolving the intercoders' 'disputes' we moved on to the analysis of the whole sample. After completion the intercoders' reliability was estimated at $97,4 \%$ of 
agreement.

\section{Results}

\section{$1^{\text {st }}$ question}

The first question the elementary teachers were asked was 'What were the positive characteristics of the Environmental Education course you attended?' and the results are presented in Table 2 as percentage of references and IET.

Table 2. Distribution of teachers' answers in each thematic category concerning the positive characteristics of the Environmental Education course.

\begin{tabular}{|c|c|c|c|}
\hline Thematic category/subcategory & $\begin{array}{l}\text { Frequency } \\
\text { (v) }\end{array}$ & $\begin{array}{l}\text { Percentage } \\
\text { Teachers }(\%)\end{array}$ & $\begin{array}{c}\text { of Percentage } \\
\text { References } \\
(\%)\end{array}$ \\
\hline Course methodology & 95 & & 39 \\
\hline $\begin{array}{l}\text { Active participation }- \text { experiential } \\
\text { approach }\end{array}$ & 47 & 81 & 19 \\
\hline Collaborative Group Teaching Method & 19 & 33 & 8 \\
\hline Variety of activities & 11 & 19 & 5 \\
\hline Linking theory and practice & 10 & 17 & 4 \\
\hline Freedom to express opinions & 4 & 7 & 2 \\
\hline Making use of teachers' experience & 2 & 3 & 1 \\
\hline Good cooperation between teachers & 2 & 3 & 1 \\
\hline Course content & 66 & & 27 \\
\hline $\begin{array}{l}\text { Clarifying the theoretical framework for } \\
\text { designing an EE school programme }\end{array}$ & 13 & 22 & 5 \\
\hline Provision of EE methodology & 10 & 17 & 4 \\
\hline Carrying out field study & 10 & 17 & 4 \\
\hline Ideas for implementing EE in school & 9 & 16 & 4 \\
\hline Multifaceted approach to subject & 8 & 14 & 3 \\
\hline Modern, up-to-date topics & 6 & 10 & 2 \\
\hline Awareness-raising, thought provoking & 6 & 10 & 2 \\
\hline Cultivating positive views on $\mathrm{EE}$ & 2 & 3 & 1 \\
\hline Background information on the history of & 2 & 3 & 1 \\
\hline
\end{tabular}


the environmental movement and EE

\begin{tabular}{llll}
\hline Course organisation & 56 & & 23 \\
\hline Well structured and organised & 29 & 50 & 12 \\
\hline $\begin{array}{l}\text { Course ran well, good presentation and } \\
\text { course methodology }\end{array}$ & 7 & 12 & 3 \\
\hline Presentation of bibliography and books & 7 & 12 & 3 \\
\hline Outline of course material from start & 6 & 10 & 2 \\
\hline Good course notes & 3 & 5 & 1 \\
\hline Audiovisual support & 2 & 3 & 0.5 \\
\hline Good time management & 1 & 2 & 0.5 \\
\hline Examination methods & 1 & 2 & 11 \\
\hline Frainer & & & 5 \\
\hline Created a positive climate & 26 & & 3 \\
\hline learners & 13 & 22 & 2 \\
\hline Clarity, communication skills & 8 & 14 & 100,0 \\
\hline Total & 5 & 9 & \\
\hline
\end{tabular}

In $39 \%$ of total responses, methodology was mentioned. Eighty-one percent $(81 \%)$ of IET described as the most positive point their active involvement in participative processes, within the experiential approach:

'The main positive point of the course was the way the trainers designed it - it allowed us to actively participate' (IET 47)

'The techniques used actively involved course participants and there was a wide variety of activities: discussion, question and answer sessions, brainstorming, role-plays, simulations etc.' (IET 1)

'The structure and the presentation of the thematic units were well organised, interesting and a variety of methodological approaches was used, while at the same time giving us first-hand experience'IET 46)

Thirty-three percent $(33 \%)$ of IET said that the collaborative group work approach was a positive teaching method, working as a simulation for future reproductions in a small 
classroom:

'Working in groups. We had firsthand experience of difficulties and limitations' (IET 51)

'Collaborative group work when filling out worksheets' (IET 57)

'Collaborative group work among training teachers, with the goal of giving them personal direct involvement in environmental topics' (IET 4)

The variety of activities (19\%), the links between theory and practice $(17 \%)$ and freedom of expression (7\%) were identified as particularly positive methodological features by IET.

Twenty-seven percent $(27 \%)$ of responses mentioned positive points about the course content. Twenty-two percent $(22 \%)$ of IET identified as positive the clarification of the theoretical framework when designing an EE school programme:

'I think that in a short time, we were given an overview of what EE means and how it can best be put into practice' (IET 8)

'The course gave us a clear theoretical framework that can be implemented in practice. Examples were given and the topics were suitable for implementation'(IET 9)

'We discovered the various parameters of the issues that EE deals with, that we were perhaps unaware of. We gained a deep understanding of some environmental concepts that we previously had only a superficial knowledge of' (IET 45)

Other positive points mentioned by IET were that they were provided with a methodology of EE $(17 \%)$, that a field study was carried out (17\%), that they were provided with ideas for implementing EE in schools (16\%), the multifaceted approach to the topic $(14 \%)$ and the up-to-date and relevant choice of topics $(10 \%)$.

Twenty-three percent $(23 \%)$ of the respondents mentioned positives in the course organization. Fifty percent $(50 \%)$ of IET judged that the course was generally well structured and organized, time was well kept and trainers were well prepared:

'Extremely well organized course, it provided all necessary resources for developing environmental programmes for elementary schools' (IET 5)

'The course materials were presented in a methodical, organized and interesting way' (IET 17)

'One positive of the course was its excellent structure and organization'(IET 18)

Additional positive points in the 'organisation' category were the way in which the course was run and presented $(12 \%)$, the fact that a rich bibliography was provided and analysed in depth in class $(12 \%)$, the outline of material given at the start of each semester $(10 \%)$ and the provision of detailed course notes $(5 \%)$.

Lastly, $11 \%$ among the references regarded the trainers. Twenty-two percent $(22 \%)$ of IET referred to the way in which trainers had created a positive atmosphere during the course: 
'Positive atmosphere throughout the course, which favoured discussion and an open exchange of ideas' (IET 27)

'A friendly atmosphere was created, where we all felt comfortable expressing ourselves spontaneously' (IET 36)

'Despite the nice atmosphere and the relaxed feeling, we didn't fall into the trap of not working, which can easily happen in such an environment' (IET 21)

Finally, there were positive comments about the trainers' attitudes to participating teachers $(14 \%)$, their generosity, their knowledge of the subject and their ability to transmit information $(9 \%)$ :

'The immediacy and clarity of the trainers, both in the way they spoke and behaved made lessons even more enjoyable'(IET 2)

'Excellent presentation by the trainer. He clearly respected his audience'(IET 27)

'The trainer has impeccable knowledge of the subject and really communicates his love for the subject' (IET 35)

'There was genuine interaction between the trainer and the audience' (IET 50)

From these results we can see that in total 243 positive points were mentioned, in other words each IET mentioned an average of at least four positive references. Thirty-nine percent (39\%) of the answers mentioned related to the course methodology and demonstrate the teachers' need for experiential activities, which they hadn't had the opportunity to experience at school or university. Twenty-seven percent $(27 \%)$ of the answers referred to the content, which shows that the teachers had gaps in their knowledge and need a holistic and multifaceted coverage of the subject. Twenty-three percent $(23 \%)$ of the answers referred to organisational choices, which shows their need for structured, well-organised refresher courses. Lastly, 11\% of the answers focused on the trainer's approach to the subject and to learners, which appears to improve the teachers' ability to empathise. Overall, it would appear that teachers' needs were met satisfactorily, as shown in some of these typical comments:

'First of all, the trainer was able to create a group dynamic. He learned everyone's name on the first day and we learned each other's. The atmosphere was very friendly. Also, the trainer organized the thematic units of each lesson at the start, and informed us of them, so we all knew what was coming up. Also, in each lesson, after the theoretical part we had some practical group activity that engaged us creatively in the process and relaxed us' (IET 42)

'Methodological training course. Experiential approach. Friendly, relaxed but at the same time brilliantly organized and scientifically up to date learning environment. I had a great time with my fellow trainees! (debate and group work)' (IET 54)

'The course attempted, and in my view succeeded to some extent, in making a positive difference to teachers' attitudes to environmental education in contemporary state schools' (IET 11) 
$2^{\text {nd }}$ question

The second question the IET were asked was: 'What were the negative characteristics of the Environmental Education course you attended?' (Table 3).

Table 3. Distribution of teachers' answers in each thematic category concerning the negative characteristics of the Environmental Education course

\begin{tabular}{llll}
\hline Thematic category/subcategory & $\begin{array}{l}\text { Frequency } \\
(v)\end{array}$ & $\begin{array}{l}\text { Percentage } \\
\text { Teachers (\%) }\end{array}$ & \begin{tabular}{c} 
of $\begin{array}{l}\text { Percentage } \\
\text { References } \\
(\%)\end{array}$ \\
\hline Course content
\end{tabular} \\
\hline Limited field study & 21 & 19 & 48 \\
\hline No visit to a CEE & 6 & 10 & 25 \\
\hline $\begin{array}{l}\text { A lot of theory in the first few } \\
\text { lessons }\end{array}$ & 4 & 7 & 9 \\
\hline
\end{tabular}

\begin{tabular}{llll}
\hline Course organisation & 17 & & 39 \\
\hline Time pressure & 8 & 14 & 18 \\
\hline Early start time of sessions & 3 & 5 & 7 \\
\hline Written final exam & 3 & 5 & 7 \\
\hline No exonerative work & 1 & 2 & 2 \\
\hline Low number of participants & 1 & 2 & 2 \\
\hline Sessions cancelled due to strikes & 1 & 2 & 2
\end{tabular}

\begin{tabular}{llll}
\hline Course methodology & 6 & & 13 \\
\hline $\begin{array}{l}\text { No design of complete EE school } \\
\text { programme }\end{array}$ & 3 & 5 & 7 \\
\hline $\begin{array}{l}\text { No other sources (images, films etc.) } \\
\text { Insufficient linking of EE with }\end{array}$ & 1 & 2 & 2 \\
economic interests & 1 & 2 & 2 \\
\hline $\begin{array}{l}\text { Formalistic approach } \\
\text { Total }\end{array}$ & 44 & & 2 \\
\hline
\end{tabular}

Thirty-three percent (33\%) of teachers' responses stressed that they found no negatives. Most of the negative points mentioned (48\%) had to do with the course content. Nineteen percent 
$(19 \%)$ of IET focused on the limited nature of the field study, which took place on a voluntary basis with no formal course requirements. However, we consider this suggestion a sign that the teachers need more experiential activities:

'The part to do with our own involvement would have been more complete if another field trip was carried out'(IET 21)

\section{'I would have preferred fewer classroom-based sessions'(IET 45)}

Ten percent $(10 \%)$ of IET stated that they needed to visit a Centre for Environmental Education (CEE), however, unfortunately, there were several formal obstacles, both from the side of the Maraslios Institute and the CEEs. Also, 7\% of IET thought that the extent of the initial theoretical section was unnecessary:

'Perhaps too much time is taken up on the theoretical part in many of the lessons' (IET 31)

'I don't think we needed so much theory in the first few lessons (or to such an extent)' (IET 22)

Thirty-nine percent (39\%) of the answers referred to organisational issues. Fourteen percent $(14 \%)$ of teachers felt under time pressure to complete the planned activities during each lesson, which testifies to the teachers' desire to carry them out undistracted:

'On the negative side, sometimes there was time pressure when we worked in groups' (IET 20)

'Not enough time for more things, visits, more projects, exercises, discussions'(IET 29)

Other negative comments related to purely procedural issues not relating to teachers' training needs, such as their dislike of the final written exam (5\%) and classes being cancelled due to strikes $(2 \%)$.

Thirteen percent $(13 \%)$ of the answers were to weak points in the course methodology. The most common comment (5\%) focused on the teachers' need to plan and present full EE school programmes even though during four sessions full EE school programmes were planned and presented.

From these responses we can surmise that IET were generally very satisfied with the course, as the negative points made were in total $1 / 5$ as frequent as the positive points. In total, 44 negative comments were made, which corresponds to each teacher making less than one. Looking at the categories into which we sorted the teachers' comments on the negative aspects of the course, we can see that $48 \%$ of comments referred to content, where teachers would have preferred even less theory, more practical work and field study and a visit to a CEE. This is in line with their responses to the previous question, where they stated that they were satisfied with the experiential activities and wanted more of them. Thirty-nine percent $(39 \%)$ of responses identified negatives in the course organisation, such as the insufficient time available (each lesson lasted less than 2 hours), the start time (for two years lessons began at $9 \mathrm{am}$, another 2 years, began at $11 \mathrm{am}$ ), the requirement to sit a written exam at the end of the semester and other operational issues, which did not however depend on the 
trainers or course director, but rather on the rules governing refresher courses, and do not reflect any needs in terms of training. Thirteen percent (13\%) of responses identified negative points in methodology, while no respondents mentioned any negative points about the trainers. We feel that even the negative comments made the course was successfully designed, as teachers seem to be calling for more lessons, more time, greater participation and more activities. It should be noted that the percentages in Table 2 record only the negative points made about the course, not taking into account the $33 \%$ of teachers who responded that there were no negative points.

\section{$3^{\text {rd }}$ question}

The third question asked 'Which elements of the course do you consider as useful for implementing Environmental Education in your school?' (Table 4).

Table 4. The usefulness of the 'Environmental Education' course for schools

\begin{tabular}{llll}
\hline Thematic category/subcategory & $\begin{array}{l}\text { Frequency } \\
(v)\end{array}$ & $\begin{array}{l}\text { Percentage } \\
\text { of Teachers } \\
(\%)\end{array}$ & $\begin{array}{l}\text { Percentage of } \\
\text { References } \\
(\%)\end{array}$ \\
\hline $\begin{array}{l}\text { Methodological elements } \\
\text { Implementation methods and strategies }\end{array}$ & 65 & 56 \\
\hline $\begin{array}{l}\text { Explanation of the planning and } \\
\text { organisation of an EE school programme }\end{array}$ & 19 & 33 & 22 \\
\hline $\begin{array}{l}\text { Ideas for activities } \\
\text { Group work }\end{array}$ & 5 & 9 & 16 \\
\hline $\begin{array}{l}\text { Field study } \\
\text { Awareness of active experiential } \\
\text { participation }\end{array}$ & 4 & 9 & 4 \\
\hline $\begin{array}{l}\text { The need for a multidisciplinary } \\
\text { approach }\end{array}$ & 3 & 5 & 3 \\
\hline \begin{tabular}{l} 
The systemic approach \\
\hline
\end{tabular} & 1 & 5 & 3 \\
\hline
\end{tabular}

\begin{tabular}{llcl}
\hline Provision of information & 33 & & 28 \\
\hline $\begin{array}{l}\text { Information about support from CEEs, } 10 \\
\begin{array}{l}\text { EE coordinators etc. } \\
\text { Information about organisations and } \\
\text { sources of materials }\end{array}\end{array}$ & 17 & 6 \\
\hline $\begin{array}{l}\text { Acquaintance with the CEEs' educational } \\
\text { materials }\end{array}$ & 6 & 10 & 5 \\
\hline
\end{tabular}




\begin{tabular}{lllll}
\hline $\begin{array}{l}\text { Presentation of complete } \\
\text { programmes }\end{array}$ & school & 4 & 7 & 3 \\
\hline Gaining self-efficacy & 4 & 7 & 3 \\
\hline The bibliography & 2 & 3 & 2 \\
\hline
\end{tabular}

\begin{tabular}{|c|c|c|c|}
\hline Theory & 18 & & 16 \\
\hline The philosophical background & 5 & 9 & 4 \\
\hline General theoretical training & 4 & 7 & 3 \\
\hline Clarification of the term 'EE' & 3 & 5 & 3 \\
\hline Basic principles of EE & 2 & 3 & 2 \\
\hline All & 2 & 3 & 2 \\
\hline Goals and targets of EE & 1 & 2 & 1 \\
\hline $\begin{array}{l}\text { Understanding of the concept of } \\
\text { sustainability }\end{array}$ & 1 & 2 & 1 \\
\hline Total & 116 & & 100 \\
\hline
\end{tabular}

Among the various comments on the usefulness of the course, most (56\%) focused on the emphasis on methodological elements. Forty-three percent $(43 \%)$ of teachers found it was particularly useful to acquire methods and EE strategies and 33\% identified the explanations of the process of designing and organising an EE school programme. It is important to note that these two points were particularly emphasised during the course:

'The structure and organization of the course - group work. EE methodology: project and problem solving methods. Basic characteristics of an EE school programme' (IET 27)

'Methods for creating and implementing an EE school programme'(IET 28)

'The main points and the guidelines for the project method'(IET 15)

'The detailed presentation of the methodology of a work plan. It gave me an ease that I think will enable me to work with these school programmes'(IET 18)

'That we were provided in a specific way with the steps and the structure of an environmental school programme'(IET 47)

'... and the process of creating an environmental school programme'(IET 8)

'How to design, implement and assess an EE school programme' (IET 23)

'The process of elaborating an EE school programme, i.e. the steps and the individual topics it should include' (IET 56)

The second most frequent category of points in terms of the usefulness of the course was that 
of information provided (28\%). Seventeen percent (17\%) of IET appreciated the information given about bodies for cooperation, $12 \%$ the information on sources of educational materials, $10 \%$ the introduction to material from the CEEs and $7 \%$ the presentation of previously applied EE school programmes. It's interesting to note the percentage of IET (7\%) that stated that through the course they gained in self-assurance and self-efficacy in terms of implementing EE in school:

'Learning these methods gives teachers a feeling of confidence'(IET 28)

'Team work makes me feel more confident about similar work in the classroom'

(IET 43)

'The course stimulated our interest, so that we want to work on this in school and put into practice everything we've learned'(IET 44)

Lastly, the theory featured in the course was deemed less useful (16\%). However, the theoretical elements seem to have triggered extensive reflective questioning amongst participating teachers, especially the emphasis on the philosophical basis (9\%), the definition of the term 'Environmental Education' (5\%), the communication of the basic principles of EE $(3 \%)$ and the understanding of the concept of sustainability $(2 \%)$.

Of the 116 useful elements of the course mentioned, over half referred to the course's focus on methodology (56\%), followed by information about organisations and educational materials $(28 \%)$ and lastly, to a lesser degree, the theoretical underpinnings of EE and its transition into Sustainability Education (16\%). This distribution shows that methodological guidance elements were the most necessary for the IET thereby vindicating their significance in the course design. Also, it seems that many teachers were unfamiliar with the organisations that they could cooperate with on EE, or get support from for their work, nor were they aware of the paper and digital educational resources available. Lastly, there was a lack of knowledge about formal procedures to be followed if they wish to draw up an EE programme in school. A smaller number of teachers considered the theoretical training to be useful, as it was covered by the reading course notes provided. Finally, two teachers stated that 'everything, all of it' would be useful. A typical response was:

'The theoretical background was useful, in particular when I clarified it to myself by reading back over the class notes, which were thorough and easy to understand. The work in groups in each lesson was also useful. Also, the introduction to CEE resources. Finally, the presentation on how environmental work plans are implemented in schools, which convinced me that successful implementation is possible' (IET 42)

\section{$4^{\text {th }}$ question}

The fourth question asked the IET 'Which elements of the course affected you on a personal level?' (Table 5). 
Table 5. Elements of the 'Environmental Education' course that personally affected the IET

\begin{tabular}{|c|c|c|c|}
\hline Thematic category/subcategory & $\begin{array}{l}\text { Frequency } \\
\text { (v) }\end{array}$ & $\begin{array}{l}\text { Percentage } \\
\text { of Teachers } \\
(\%)\end{array}$ & $\begin{array}{l}\text { Percentage of } \\
\text { References } \\
(\%)\end{array}$ \\
\hline Methodological elements & 35 & & 46 \\
\hline The collaborative group approach & 9 & 16 & 12 \\
\hline $\begin{array}{l}\text { Detailed presentation of methods and } \\
\text { strategies }\end{array}$ & 8 & 14 & 11 \\
\hline $\begin{array}{l}\text { The difficulty of setting targets in an EE } \\
\text { school programme }\end{array}$ & 4 & 7 & 5 \\
\hline $\begin{array}{l}\text { Presentation of complete school } \\
\text { programmes }\end{array}$ & 4 & 7 & 5 \\
\hline $\begin{array}{l}\text { Information about educational resources } \\
\text { and how to find them }\end{array}$ & 4 & 7 & 5 \\
\hline $\begin{array}{l}\text { Experiential activities with active } \\
\text { participation }\end{array}$ & 3 & 5 & 4 \\
\hline The field study & 1 & 2 & 1 \\
\hline $\begin{array}{l}\text { Implementation of multidisciplinary } \\
\text { approach }\end{array}$ & 1 & 2 & 1 \\
\hline $\begin{array}{l}\text { The criterion that the subject must } \\
\text { interest students }\end{array}$ & 1 & 2 & 1 \\
\hline Thoughts and feelings about EE & 23 & & 30 \\
\hline $\begin{array}{l}\text { I feel able to implement an EE school } \\
\text { programme }\end{array}$ & 10 & 17 & 13 \\
\hline Optimism and enthusiasm & 3 & 5 & 4 \\
\hline $\begin{array}{l}\text { Clarification of the structure of an EE } \\
\text { school programme }\end{array}$ & 3 & 5 & 4 \\
\hline $\begin{array}{l}\text { Holistic meaning and need for further } \\
\text { study of EE }\end{array}$ & 2 & 3 & 3 \\
\hline Change of attitude towards EE & 2 & 3 & 3 \\
\hline Concerns about the difficulties of EE & 2 & 3 & 3 \\
\hline History of EE & 1 & 2 & 1 \\
\hline Philosophical elements & 18 & & 24 \\
\hline $\begin{array}{l}\text { Thinking about philosophical and ethical } \\
\text { issues }\end{array}$ & 6 & 10 & 8 \\
\hline
\end{tabular}




\begin{tabular}{llll}
\hline Increased environmental awareness & 5 & 9 & 7 \\
\hline Need to shape active citizens & 3 & 5 & 4 \\
\hline Trainer - teacher interaction & 2 & 3 & 3 \\
\hline The discussion on sustainability & 1 & 2 & 1 \\
\hline The need to link school with daily life & 1 & 2 & 1 \\
\hline Total & 76 & & 100 \\
\hline
\end{tabular}

Only $10 \%$ of IET said that they were not affected by the course. The rest of the responses are displayed in Table 4, grouped by topic. Most responses referred to elements of methodology $(46 \%)$. Sixteen percent (16\%) of IET said that they had been affected by their participation in collaborative group activities, as they experienced the group process within the limitations that it presents:

'Cooperating with others in a group taught me to accept all points of view and weigh them up'

(IET 22)

'The ideas, views and thoughts about environmental issues during group exercises, discussions and activities' (IET 4)

Fourteen percent (14\%) of IET were satisfied with the detailed presentation of methods and strategies, $7 \%$ mentioned the presentation of complete EE school programmes, $7 \%$ were surprised at how difficult it was to create targets in an EE school programme, 7\% thought it was useful finding out about the existence of educational resources and $5 \%$ enjoyed the experiential activities with active participation.

Thirty percent $(30 \%)$ of responses referred to the different thoughts and feelings about EE. Seventeen percent $(17 \%)$ of IET said that they felt secure and confident in implementing EE in school:

I feel that I've become informed about something I didn't know about and I feel that my methods have been brought up to date. I also feel more confident about implementing a relevant school programme' (IET 28)

'There had been a sense of insecurity in terms of implementing EE programme at school, but now I feel confident. We worked in teams and on specific topic. I know I should not be approaching environmental issues superficially but in depth' (IET 43)

Five percent (5\%) of IET said that they felt optimistic and enthusiastic after having followed the course. A further 5\% was satisfied with the clarification of the structure of an EE school programme. Three percent (3\%) of IIET stated that they had discovered the holistic meaning of, and the need for further study of EE, while at the same time worrying about the difficulties they would face in successfully implementing an EE school programme. A further $3 \%$ said that they had changed their views on EE, whereby they were initially cautious or 
negative about getting involved with it.

Twenty-four $24 \%$ of responses referred to reactions to ethical and philosophical issues:

'Moving from Anthropocentrism to Deep Ecology'(IET 29)

'The way that the anthropocentric and biocentric models were taught' (IET 14)

\section{'Considering philosophical and ethical issues' (IET 35)}

Ten percent (10\%) of IET cited thinking about philosophical and ethical issues and $9 \%$ said it increased their environmental awareness. Five percent (5\%) saw the need to form active citizens and $3 \%$ were affected by the trainer-teacher interaction.

Overall of the 76 references to elements that affected IET personally, around half referred to methodology (46\%), followed by thoughts and feelings about EE (30\%) and then more general reactions to the philosophical - ethical questions linked to the environment $(24 \%)$. It is clear that the methodological elements experienced by teachers during the course were not only judged to be useful in terms of their implementation in school, but also affected the way they personally approached EE and wider issues. Participating in collaborative group work, the difficulties experienced in putting various strategies into practice, active participation, disagreements over how to set targets and other elements led teachers to think about what they ask students to do, how much time they give to them, whether they give them enough guidance and how much they should intervene during EE activities and more generally in the classroom. It is important to note that many felt they were capable of implementing EE school programme, changed their previously-held negative attitude towards EE, clarified the structure and progression of an EE school programme and expressed feelings of optimism and enthusiasm. Finally, many said that they had reflected on philosophical and ethical matters that they hadn't heard of before, increased their environmental awareness, felt confirmed in their need to shape active citizens through education, observed that EE is a way of connecting school to the outside world, were affected by the image of a trainer who did not impose strict limits to activities and reconsidered their role as educators.

\section{Discussion - Teaching Implications}

We believe that we have seen 'the two-sided coin' proposed by Meyers $(2006,460)$ by 'constructing a productive learning environment and facilitating a learning process intended to bring about (educator) valorised changes in the learner'. Our educational approach falls within the framework of constructivist learning theory, as the IET were involved in activities that held meaning for them and they had opportunities to build their own personal understanding of environmental issues through participatory research, critical reflection or issue investigation. Although activities were guided, teachers faced dilemmas, investigated values, weighed up contradictory interests and made decisions on hypothetical problems.

The cited extracts from teachers' responses are the 'evidence base' proposed by Rickinson (2001), indicating their educational experiences and preferences. The characteristics of the course as experienced by the teachers can be distinguished through their comments. The importance of these comments can be judged on the one hand by their spontaneous responses 
to the open questions of the questionnaire and on the other hand by the reaction that they themselves feel they had in terms of their knowledge, attitudes and behaviour.

IET had a positive view of their active engagement in learning activities, in contrast to relevant studies (Nielsen et al., 2012) referring to pre-service elementary teachers (PET), who reported feeling insecure with student-centred methods and mostly preferred teacher/lecturer-centred as they felt the latter left them with more certainty about the way they will deal with environmental education. In our research we found that IET prefer to be involved in experiential activities, feeling that they can transfer them directly to their classroom. More generally, the course design followed the principle that 'teachers tend to teach the way they were taught' (Martin, 2012, 270). Breaking this cycle requires a different emphasis on pedagogy in teacher education.

The quantity and range of activities were seen as the most important point in lesson planning, which met IET' needs. With activity as a tool, IET had the opportunity to approach the theory of EE through practical experience: problem solving, reading exercises, conceptual maps, presentations, structured discussions, field studies. In this way they were personally involved, they could express themselves creatively, work in groups and contemplate their daily work in schools, while at the same time observing the complexity of the issues both at local and global level. They gained experience of being a learner, they experienced processes and entered a context specifically designed for EE that they could, with a few adjustments, transfer to their classroom.

We find it an important result that IET had the opportunity to step into the learners' shoes and in doing so, improve their ability to empathise. It is easier for this to occur in EE as it is not another school subject imparted directly by teachers to students, but a longer process that requires creativity, imagination, sensitivity, critical thought, reflection on the part of the teacher and the intervention of appropriately designed activities. Thus, EE can become the vehicle with which to introduce more active, experiential and learner-centred methods into other subjects across the school curriculum.

Teachers' assessments of the 'Environmental Education' course they followed are positive and vindicate the fundamental methodological choices, such as practical work, connecting theory with practice, collaborative group work and experiential activities. These principles seem to be effective and should govern any training course for teachers or pupils in the context of EE. In our case they satisfied teachers' needs.

Obviously, the results of our research cannot be generalised, given the limited sample size. In order to observe the long-term impact of the course on IET, more research would be needed into how teachers implemented the knowledge and competences they acquired during the course and into their ability to design EE school programmes in the way they were taught. Other avenues for further research are the duration of the positive learning experiences, their conversion into appropriate learning activities and the transfer of the experiences and processes to the classroom. 


\section{References}

Antoniou, E. (2010). Empirical research in secondary teachers' training in the context of sustainability. In Proceedings of 5th Pan-Hellenic Conference of the Hellenic Association of Educators of Environmental Education, Ioannina, 26-28/11/2010. (in Greek) http://kpe-kastor.kas.sch.gr/peekpe/proceedings/synedria_4_ereunes/Antoniou.pdf

Babbie, E. (2011). The Practice of Social Research (12 ${ }^{\text {th }}$ ed.). Belmont, CA: Wadsworth, Cengage Learning.

Berelson, B. (1984). Content analysis in communication research. New York: Hafner.

Berg, H., \& Veer, K. (1988). Semantic validity - Testing the operationalization of ideological frames of reference. Quality \& Quantity, 22(3), 311-330. http://link.springer.com/article/10.1007\%2FBF00183543\#page-1

Carolan, M.S. (2006). Scientific knowledge and environmental policy: why science needs $\begin{array}{llll}\text { values. } & \text { Environmental 229-237. }\end{array}$ http://dx.doi.org/10.1080/15693430601058224

Carr, W., \& Kemmis, S. (1986). Becoming Critical: Education, Knowledge, and Action Research. Geelong: Deakin University Press.

Carter, L. (2007). Sociocultural Influences on Science Education: Innovation for Contemporary Times. Science Education, 92, 165-181. http://dx.doi.org/10.1002/sce.20228

Christie, B. A., Miller, K. K., Cooke, R., \& White, J. G. (2012). Environmental sustainability in higher education: how do academics teach? Environmental Education Research, 19(3), 385-416. http://dx.doi.org/10.1080/13504622.2012.698598

Daskolia, M.K. (2000). Secondary education teachers' in-service training needs in environmental education. Unpublished doctoral thesis, Faculty of Philosophy, Education, and Psychology. Athens: National and Kapodistrian University of Athens, Greece. (in Greek)

Daskolia, M. \& Flogaitis, E. (2003). Theoretical Formulation and Empirical Investigation of a Conceptual Model of Teachers' Competence in Environmental Education. Canadian $\begin{array}{lllll}\text { Journal of Environmental 249-267. } & \text { Education, }\end{array}$ http://cjee.lakeheadu.ca/index.php/cjee/article/view/250

Dimopoulou, M. \& Babila, E. (2010). Evaluation of the training needs of elementary teachers who implement EE programmes in $\mathrm{A}^{\prime}$ Athens region. In Proceedings of 5th Pan-Hellenic Conference of the Hellenic Association of Educators of Environmental Education, Ioannina, 26-28/11/2010. (in

Greek) http://kpe-kastor.kas.sch.gr/peekpe/proceedings/synedria_9_ereunes/Dimopoulou_Babila.pdf

Dobson, A. (1998). Justice and the Environment: Conceptions of Environmental Sustainability and Theories of Distributive Justice. Oxford: Oxford University Press.

Fikaris, I. (1998). Environmental Education in teacher training in Greece. Thessaloniki: Kiriakidis bros. (in Greek) 
Fleming, L. (2010). Teachers' needs. Professional development priorities of formal pre K-20 environmental educators. EETAP - University of Wisconsin. http://cms.eetap.org/repository/moderncms_documents/teachers_needs_final_sm_2.24.pdf

Flogaitis, E. (1998). Environmetal Education. Athens: Ellinika Grammata. (in Greek)

Flogaitis, E. (2006). Education for the Environment and Sustainablity. Athens: Ellinika Grammata. (in Greek)

Freire, P. (1972). Pedagogy of the Oppressed. Harmondsworth, UK: Penguin Books

Gayford, C. (2002). Controversial environmental issues: a case study for the professional development of science teachers. International Journal of Science Education, 24(11), 1191-2000. http://dx.doi.org/10.1080/09500690210134866

Giannakouras, I., Zaravela, D., \& Mandrikas, A. (2008). Renewable energy resources. Educational material of open environmental classes "KALLISTO". Available at http://www.e-yliko.gr/htmls/perivallon/kallisto_files_/ananeos_piges_energ.pdf

Gibson, R. (1986). Critical Theory and Education. London: Hodder ans Stoughton.

Giroux, H. A., \& McLaren, P. (1994). Between Borders: Pedagogy and the Politics of Cultural Studies. New York: Routledge.

Graneheim, U.H., \& Lundman, B. (2004). Qualitative content analysis in nursing research: concepts, procedures and measures to achieve trustworthiness. Nurse Education Today, 24(2), 105-112. http://www.ncbi.nlm.nih.gov/pubmed/14769454

Grawitz, M. (2001). Méthodes des sciences socials (11e éd.). Paris: Dalloz.

Heimlich, J. E., Braus, J., Olivolo, B., McKeown-Ice, R., Barringer-Smith, L., \&. (2004). Environmental Education and Pre-service Teacher Preparation: A National Study. The Journal of Environmental Education, 35(2), 17-21. DOI: 10.3200/JOEE.35.2.17-60

Kaztaridou, A. (2007). Training needs of elementary teachers in Environmental Education. In Proceedings of 3rd Pan-Hellenic Conference of the Hellenic Association of Educators in Environmental Education Education, Athens, 9-11/11/2007. (in Greek) http://kpe-kastor.kas.sch.gr/peekpe/1_ereuna/Kaztaridou.pdf

Kelley, R. L. (2010). An Innovative and Practical Course for Environmental Educators. Applied Environmental Education and Communication, 9, 243-250. http://dx.doi.org/10.1080/1533015X.2010.530891

Kemmis, S., \& Mutton, R. (2012). Education for sustainability (EfS): practice and practice architectures. Environmental Education Research, 18(2), 187-207. http://dx.doi.org/10.1080/13504622.2011.596929

Klein, B. S. (2001). Guidelines for effective elementary science teacher inservice education. Journal of Elementary Science Education, 13(2), 29-40. http://link.springer.com/article/10.1007\%2FBF03176218\#page-1 
Klein, B. S. (2005). Application of the Guidelines for Effective Elementary Science Teacher Inservice Education. Journal of Elementary Science Education, 17(2), 57-72. http://link.springer.com/article/10.1007\%2FBF03174681\#page-1

Lacy, S., \& Riffe, D. (1996). Sampling error and selecting intercoder reliability samples for nominal content categories: Sins of omission and commission in mass communication quantitative research. Journalism \& Mass Communication Quarterly, 73(4), 963-973. http://dx.doi.org/ 130.203.133.150

Lee, O., Hart, J. E., Cuevas, P., \& Enders, C. (2004). Professional development in inquiry-based science for elementary teachers of diverse student groups. Journal of Research in Science Teaching, 41(10), 1021-1043. http://dx.doi.org/10.1002/tea.20037

Littledyke, M. (2008). Science education for environmental awareness: approaches to integrating cognitive and affective domains. Environmental Education Research, 14(1), 1-17. http://dx.doi.org/10.1080/13504620701843301

Locke, S. (2009). Environmental education for democracy and social justice in Costa Rica. International Research in Geographical and Environmental Education, 18(2), 97-110. http://dx.doi.org/10.1080/10382040902861171

Mandrikas, A. (2012). Towards a critical environmental education for pre-service elementary teachers. Kritiki: Science and Education, 12, 29-44. Athens: Nisos (in Greek) http://www.hpdst.gr/publications/articles

Martin, D. (2012). Elementary Science Methods: A Constructivist Approach (6th ed.) Belmont, CA: Wadsworth.

Matsagouras, I. (1998). Teaching Strategies - Critical Thinking in Didactical Praxis. Athens: Gutenberg (in Greek).

Mavrikaki, E, Antonatou, C., \& Kyridis, A. (2012). Greek Senior High School Students' Perceptions about Science and the Scientific Community as These Appear in the Mass Media. Journal of Studies in Education, 2(4), 32-46. http://dx.doi.org/10.5296/jse.v2i4.2270

Meichtry, Y., Zint, M., Carlsen, W., Hart, P., Sammel, A., Zandvliet, D., \& Dillon, J. (eds) (2001). Relations between Science Education and Environmental (Science) Education. Paper presented at the annual meeting of the National Association for Research in Science Teaching. St. Louis, MO, March 27, 2001. Retrieved from http://www.nku.edu/ scienceed/NARST_319.PDF

Meyers, R. B. (2006). Environmental learning: reflections on practice, research and theory. Environmental Education Research, 12(3-4), 459-470. http://dx.doi.org/10.1080/13504620600799216

Michail, S., Papadimitriou, E., Athanassiou, C. \& Aggelidis, Z. (2008). Training activity of the Environmental Education Centre in Eleftherio-Kordelio - Evaluation of teachers' training needs and desires in EE in Thessaloniki region. In Proceedings of 4th Pan-Hellenic Conference of the Hellenic Association of Educators of Environmental Education, Nafplio, 
http://kpe-kastor.kas.sch.gr/peekpe4/proceedings/synedria9/mixail.pdf

Monroe, M. C., \& Fien, J. (2005). The Role Environmental Education Might Play in the Decade for Education for Sustainable Development. Applied Environmental Education and Communication, 4(3), 203-206. http://dx.doi.org/10.1080/15330150591004562

Mucchielli, R. (2006). L'analyse de contenu des documents et des communications. Paris: ESF.

Neuendorf, K.A. (2002). The content analysis guidebook. Thousand Oaks, California: Sage Publications, Inc.

Nielsen, W., Andersen, P., Hurley, A., Sabljak, V., Lee Petereit, A., Hoskin, V., \& Hoban, G. (2012). Preparing Action Competent Environmental Educators: How Hard Could It Be? Australian Journal of Environmental Education, 28, 92-107. http://dx.doi.org/10.1017/aee.2013.3

Omoogun, A. C. \& Omoogun, R. M. (2013). Inservice Training Programme Preference of Teachers in the Multidisciplinary Approach of Implementing Environmental Education. Journal of Studies in Education, 3(2), 255-263. http://dx.doi.org/10.5296/jse.v3i2.3469

Papadimitriou, V. (1995). Professional Development of In-service Primary Teachers in Environmental Education: An Action Research Approach. Environmental Education Research, 1(1), 85-97. http://dx.doi.org/10.1080/1350462950010107

Papaioannou, I., Vlachos, I., Papasotiropoulou, K. \& Antonakopoulou, E. (2010). 'We were two, we were three, now we are thousand thirteen...', Teachers' training in EE in Achaia region between 2005-2010. In Proceedings of 5th Pan-Hellenic Conference of the Hellenic Association of Educators of Environmental Education, Ioannina, 26-28/11/2010 (in Greek). http://kpe-kastor.kas.sch.gr/peekpe/proceedings/synedria_12_Dia_Biou/Papaioannou_et_al.p df

Powers, A. L. (2004). Teacher Preparation for Environmental Education: Faculty Perspectives on the Infusion of Environmental Education into Pre-service Methods Courses. The Journal of Environmental Education, 3-11. http://www.peecworks.org/PEEC/PEEC_Research/01795C12-001D0211.0/Powers\%20teache r\%20prep.pdf

Rickinson, M. (2001). Learners \& Learning in Environmental Education: a critical review of the evidence. Environmental Education Research, 7(3), 207-320. http://dx.doi.org/10.1080/1350462012006523 0

Sandholtz, J.H. (2002). Inservice training or professional development: contrasting opportunities in a school/university partnership. Teaching and Teacher Education, 18(7), 815-830. http://dx.doi.org/10.1016/S0742-051X(02)00045-8Sauvé, L., \& Berryman, T. (2005). Challenging a "Closing Circle": Alternative Research Agendas for the ESD Decade. Applied Environmental Education and Communication, 4(3), 229-232. 
http://dx.doi.org/10.1080/15330150591004634

Schiza, C. (2008). Systemic thinking and Environmental Education. Athens: C. E. Dardanos (in Greek).

Skordoulis, C. (2005). Introduction to Environmental Philosophy. Athens: National and Kapodistrian University of Athens (in Greek).

Skordoulis, C., \& Sotirakou, M. (2005). Environment: Science and Education. Athens: Leader Books (in Greek).

Stevenson, R. B. (2007). Schooling and environmental/sustainability education: from discourses of policy and practice to discourses of professional learning. Environmental Education Research, 13(2), 265-285. http://dx.doi.org/10.1080/13504620701295650

Summers, M., Corney, G., \& Childs, A. (2003). Teaching Sustainable Development in Primary Schools: an empirical study of issues for teachers. Environmental Education Research, 9(3), 327-346. http://dx.doi.org/10.1080/13504620303458

UNESCO (2005). UN Decade of Education for Sustainable Development 2005-2014, Draft International Implementation Scheme. Paris, ED/2005/PI/H/1. http://unesdoc.unesco.org/images/0014/001486/148654e.pdf

Weber, R.P. (1990). Basic Content Analysis (2nd ed.). Newbury Park, California: Sage University Paper. Zagkos, Ch., Kyridis, A., Golia, P., \& Vamvakidou, I. (2007). Greek university students describe the role of Greece in Balkans: from equality to superiority. Nationalities Papers, 35(2), 341-367. http://dx.doi.org/10.1080/00905990701254383 